\title{
EFFECTS OF WATER DEFICIT IN TWO PHENOLOGICAL STAGES ON PRODUCTION OF JAPANESE CUCUMBER CULTIVED IN GREENHOUSE
}

\author{
EDUARDO C. OLIVEIRA ${ }^{1}$, JACINTO DE A. CARVALHO ${ }^{2}$, \\ WELLINGTON G. DA SILVA ${ }^{3}$, FÁTIMA C. REZENDE ${ }^{4}$, WILLIAN F. DE ALMEIDA ${ }^{5}$
}

\begin{abstract}
The experiment was performed in the experimental area of the Engineering Department Federal University of Lavras, Minas Gerais State, Brazil. It aimed at identifying the adequate irrigation management of the greenhouse-cultivated Japanese cucumber (Cucumis sativus L.). complete randomized design, with four levels of soil water potential $(15 ; 30 ; 60 \mathrm{e} 120 \mathrm{kPa})$ at two phenological phases (vegetative and reproductive), and 5 replications. Overall, the results showed decrease of yield according to increase of soil water potentials. During the reproductive stage, Japanese cucumber plants were more sensitive to water deficit, resulting in further decrease in yield compared to applied water deficit during the vegetative stage of the culture.
\end{abstract}

KEYWORDS: Cucumis sativus L., greenhouse, irrigation management.

\section{EFEITO DO DÉFICIT HÍDRICO EM DUAS FASES FENOLÓGICAS SOBRE A PRODUÇÃO DO PEPINO-JAPONÊS CULTIVADO EM AMBIENTE PROTEGIDO}

RESUMO: O experimento foi realizado na área experimental do Departamento de Engenharia da Universidade Federal de Lavras, em Lavras - MG, e teve como objetivo identificar um manejo adequado da irrigação para a produção do pepino-japonês (Cucumis sativus L.) cultivado em ambiente protegido. Foi utilizado um delineamento inteiramente casualizado, envolvendo, como tratamentos, quatro níveis de potencial de água no solo $(15 ; 30 ; 60$ e $120 \mathrm{kPa})$ em duas fases fenológicas da cultura (vegetativa e reprodutiva), com 5 repetições. De forma geral, os resultados mostraram decréscimo da produtividade de acordo com o incremento do potencial de água no solo; as plantas do pepineiro-japonês, quando na fase reprodutiva, mostraram-se mais sensíveis ao déficit hídrico, redundando em maiores quedas de produtividade em comparação com o déficit hídrico aplicado durante a fase vegetativa da cultura.

PALAVRAS-CHAVE: Cucumis sativus L., manejo da irrigação, produtividade.

\section{INTRODUCTION}

Cucumber is among the ten commercially most relevant vegetable crops in Brazil, being the Japanese cucumber a valued cultivar. It produces fruits appreciated in demanding markets, such as in São Paulo city, due to its typical and pleasant flavor. The Japanese cucumber produces typically thin and elongated fruits, $20-30 \mathrm{~cm}$ long, with a dark green color. These fruits do not hold seeds, since all cultivars of this group are gynoid-parthenocarpic hybrids. This crop requires trellis and can be cultivated in closed greenhouses, and pollination is avoided because it modifies the fruit shape (FILGUEIRA, 2003). Moreover, cultivation of the Japanese cucumber in greenhouses enables the use of hybrids with high yield potential (LALLA et al., 2010).

There has been a significant increase in the planted area under protected environment in Brazil during the last decades, especially for vegetable and flower production (MAGGI et al.,

\footnotetext{
${ }^{1}$ Eng ${ }^{\mathrm{o}}$ Agrícola, M.Sc. em Engenharia de Água e Solo, Doutorando em Recursos Hídricos em Sistemas Agrícolas, Departamento de Engenharia, UFLA, Lavras - MG, eduardoco@oi.com.br. Bolsista FAPEMIG.

${ }^{2}$ Prof. Associado III, Departamento de Engenharia, UFLA, Lavras -MG, jacintoc@ufla.br. Bolsista CNPq.

${ }^{3}$ Eng $^{\mathrm{o}}$ Agrônomo, Doutorando em Engenharia Agrícola (DEG/UFLA).

${ }^{4}$ Eng ${ }^{\mathrm{o}}$ Agrícola, D.Sc. em Irrigação e Drenagem, Pesquisadora, Departamento de Engenharia, UFLA: frezende@ deg.ufla.br.

${ }^{5}$ Tecnólogo em recursos hídricos/irrigação, Doutorando em Engenharia Agrícola, Departamento de Engenharia, Universidade Federal de Lavras - UFLA, C. P. 3037, Lavras - MG, Fone: (0XX35) 3829.1362,wifatec@yahoo.com.br.

Recebido pelo Conselho Editorial em: 10-8-2009

Aprovado pelo Conselho Editorial em: 3-5-2011
} 
2006). This cropping system allows obtaining produces of higher quality and higher yields, as well as reducing seasonal effects.

Briefly, irrigation is among the technologies that promote yield increase in crops (OLIVEIRA et al., 2008). In protected environments, irrigation is an essential technique, but a bad management of this technique may hamper production. Several authors confirmed that irrigation promotes yield increases in several vegetables, such as AYAS \& DERMITAS (2009), ERTEK et al. (2006) and YUAN et al. (2006) for cucumber; BILIBIO et al. (2010) for eggplant; DERMITAS \& AYAS (2009) for bell pepper; VILAS BOAS et al. (2008) for crisp lettuce; ARAÚJO et al. (2010) and ZENG et al. (2009) for melon.

In order to guarantee crop success, irrigation must be carried out before the soil water availability is reduced to levels that change the plant's metabolism, leading to decreased yields. Thus, water deficiency is one of the most limiting factors to obtain high yields, especially in vegetable crops under protected environments, or in the field (GUANG-CHENG et al., 2008; PATANÈ \& COSENTINO, 2010).

During the vegetative or developmental phase of the crops, water deficit leads to an adverse effect on yield, reducing it more dramatically than when it is applied in a continuous manner (SEZEN et al., 2006). Furthermore, crop water deficit may significantly affect yields and the qualitative aspects of the fruit, particularly when it occurs during the flowering phase or during the reproductive period (AUJLA et al., 2007; LOVELLI et al., 2007; POSSE et al., 2009).

On the other hand, crop management with application of water deficit may be environmentally and economically beneficial (FERERES \& SORIANO, 2007). According to RODRIGUES \& PEREIRA (2009), farmers may adopt deficit irrigation to cope with limiting water availability during droughts, making this method of great importance to agriculture. Moreover, the water saved by deficit irrigation may be used to irrigate other areas, which given the opportunity cost of water, it may largely be compensated by the economical loss due to yield reduction (ALI et al., 2007).

Regarding irrigation management, the decisive factor to be followed in order to apply this technique is based on knowing the water-soil-plant-atmosphere relations. It is necessary to know the behavior of each crop as a function of the different quantities of water supplied, establish the developmental phases of most intense water consumption, and the critical periods when the lack or excess of water leads to yield losses (BERNARDO et al., 2006).

Little is know about the effects of water stress during the different stages of crop development of the Japanese cucumber. However, it is know that most vegetable crops present periods of more or less susceptibility to soil water deficits. Thus, this work aimed at evaluating the effect of different soil water potentials during two phenological phases (vegetative and reproductive) on crop yields of the Japanese cucumber cultivated in greenhouse.

\section{MATERIAL AND METHODS}

The experiment was carried out in a greenhouse located in the experimental area of the Engineering Department at the Universidade Federal de Lavras (UFLA), in the municipality of Lavras, state of Minas Gerais, Brazil. The climate of the regions is classified as Cwa, according to Köeppen's classification, i.e., mild temperate climate, rainy with dry winter (DANTAS et al., 2007). The mean annual air temperature is $19.4{ }^{\circ} \mathrm{C}$, with a mean minimum of $14.8{ }^{\circ} \mathrm{C}$, and a mean maximum of $26.1{ }^{\circ} \mathrm{C}$. The mean relative air humidity is $76.2 \%$, and the annual mean of precipitation and evaporation are $1,529.7 \mathrm{~mm}$ and $1,034.3$, respectively.

The maximum and minimum relative humidity (RH), and maximum and minimum temperature $\left(\mathrm{T}^{\circ}\right)$ were measured daily by thermohygrometer placed in a container within the greenhouse. 
The soil of the experimental area was originally classified as Dystroferric Red Latosol. A representative composed sample was collected considering as layer the bed height at $0.25 \mathrm{~m}$, and sent to the Soil Physics and the Soil Fertility laboratories at UFLA's Soil Sciences Department for physical and chemical analyses, respectively.

The physical analysis produced the water retention curve of the soil for the layer between 0 and $0.25 \mathrm{~m}$ deep. The porous plate funnel method was used to determine water soil potentials of 2; $4 ; 6 ; 8$ and $10 \mathrm{kPa}$, and the Richard's pressure chamber for the potentials of 33;100;500 and $1,500 \mathrm{kPa}$. The adjustment parameters of the equation of characteristic curve of soil water (eq.(1)), according to the model by GENUCHTEN (1980), was obtained using the SWRC software version 3.0 (DOURADO NETO et al., 1995) with a coefficient of determination $\left(\mathrm{R}^{2}\right)$ of $98.8 \%$.

$$
\theta=0.235+\left(\frac{0.674-0.235}{\left[1+(0.2749 \psi)^{2.0272}\right]^{0.5067}}\right)
$$

where,

$\theta$ - current humidity based on volume, $\mathrm{cm}^{3} \mathrm{~cm}^{-3}$, and

$\Psi$ - soil water potential, $\mathrm{kPa}$.

The experiment consisted of a completely randomized design (CRD) involving four levels of soil water potential $(15 ; 30 ; 60$ e $120 \mathrm{kPa}$ ), in two phenological phases of the crop cycle (the vegetative phase: from post-emergence until start of flowering of $50 \%$ of the plants, and; the reproductive phase: from the end of the vegetative phase until the complete maturation of the fruits and end of the useful cycle of the plants), with five repetitions. Each experimental unit consisted of a bed with two plants spaced $1.1 \times 0.4 \mathrm{~m}$. The beds were delimited by black polyethylene film buried at $0.4 \mathrm{~m}$ depth to avoid water movement between beds.

A localized irrigation system was adopted, using self-compensating drippers working between the pressure range recommended by the fabricant, with $2.4 \mathrm{~L} \mathrm{~h}^{-1}$ flow, inserted in a dripping pipe installed at the plant line of the beds, with one dripper per plant. Valves for each treatment were installed in the head control, being individually triggered and shut according to the irrigation time defined for each water potential, to elevate soil humidity to the soil field capacity, which was $10 \mathrm{kPa}$ and was obtained through on-site test.

Irrigation time was established according to pre-determined soil water potentials $(15 ; 30 ; 60 \mathrm{e}$ $120 \mathrm{kPa}$ ) for each of the phenological phases analyzed (vegetative and reproductive). A value of $15 \mathrm{kPa}$ was used to irrigate the plants that were not associated with the treatments described.

Three tensiometers were installed, in three experimental units of each treatment to monitor potentials of 15; 30 e $60 \mathrm{kPa}$, along with three sensors of grain matrix to monitor the potential of $120 \mathrm{kPa}$, being all of them installed at a depth of $0.125 \mathrm{~m}$, considering $0.25 \mathrm{~m}$ as the effective mean depth of this crop's root system from the beginning of the treatment until the end of the evaluated cycle. Readings of the tensiometers were made with a digital puncture tensiometer and, for the grain matrix sensors, the potentials were obtained with a Watermark ${ }^{\circledR}$ reading equipment. Values of soil water potentials were taken twice a day, and irrigation was applied when at least two of the readings of soil water potential values showed a value recommended for irrigation.

To obtain water use efficiency (WUE) during the vegetative phase, total values of applied water and water deficit (soil water potentials) during the vegetative phase were considered, and irrigation with values of soil water potentials of $15 \mathrm{kPa}$ during the reproductive phase of the crop cycle. Conversely, to calculate WUE during the reproductive phase, it was considered the total amounts of water applied with potential values of $15 \mathrm{kPa}$ during the growing season and during treatments with irrigation water deficit during the reproductive cycle of the culture. 
The variety of Japanese cucumber used in the experiment was the cultivar Master Green. Plants were sown in 128-cell trays. After the plantlets reached an average height of $0.05 \mathrm{~m}$, they were transferred to the experimental units (beds). The experiment started with plantlet transfer in August 29, 2008 and finished with the last harvest in November 28, 2008, totaling 91 days of cultivation.

The application of the treatments started at 18 days after transplanting (DAT), period which was necessary to allow adaptation and standardization of the plantlets. Treatments during the vegetative phase of the crop lasted until 50 DAT in function of changes of the observed phase in $50 \%$ of the plants, after which period all plants were irrigated when the soil water potential reached $15 \mathrm{kPa}$ to replenish the soil with water to field capacity $(10 \mathrm{kPa})$. Conversely, treatments relative to the reproductive phase started at 50 DAT. Plants under this treatment were irrigated to field capacity of $15 \mathrm{kPa}$ during the vegetative phase.

Fertilization at planting and topdressing were carried out manually based on chemical analyses of the soil and according to recommendation by GOMES et al. (1999) for cucumber. Plants were guided in trellis using eight strands of smooth wire attached longitudinally at the bed sides in eucalyptus stakes up to $2.0 \mathrm{~m}$.

At 40 DAT, all fruits and leaves located up to the fifth internode of the plants were stripped. Development of two branches per internode was allowed from the sixth internode, and these were pruned after the third internode. Decapitation was performed after the $22^{\text {th }}$ internode, in order to avoid indeterminate growth beyond $2.0 \mathrm{~m}$ in height above the strands of wire used in staking.

Disease control was carried out preventively with fortnightly sprays of Maconzeb-based fungicides, and weekly with copper-based fungicides. At the early fruiting period, during an onset of mildew symptoms, a sulfur-based fungicide was sprayed. Were also applied weekly insecticides for pest control, including aphid and whitefly, which are vectors of the mosaic virus and of gourd tospoviruses. Weed control was accomplished through manual weeding.

Fruit harvest started at 55 DAT, at intervals of one to two days, depending on the time required for the fruit to reach the harvest point. They were counted and weighted, accounting only for fruits classified commercially, comprising fruits measuring between 20 and $24 \mathrm{~cm}$ in length, flawless conformation (no attack of pests and diseases) and deformations, as recommended by CEASA-MG (2009). Yield was assessed by the number and weight of the fruits produced per plant, according to each treatment.

The data were subjected to analysis of variance, using the F-test of distribution at 5\% probability, and the means were compared by regression. Statistical analysis was performed using the software SISVAR, by FERREIRA (2008).

\section{RESULTS AND DISCUSSION}

The mean temperature in the greenhouse during the experiment was $26.2^{\circ} \mathrm{C}$, with means of maximum and minimum temperatures of $32.6{ }^{\circ} \mathrm{C}$ and $15.6^{\circ} \mathrm{C}$, respectively. The mean relative humidity was $58 \%$ with mean values of $73 \%$ and $42 \%$ for maximum and minimum, respectively. SGANZERLA (1995) reported that the ideal humidity range lies between $70 \%$ and $90 \%$, and the optimum temperatures for a good development of cucumber are between $20^{\circ} \mathrm{C}$ and $25^{\circ} \mathrm{C}$ during the day, and $18{ }^{\circ} \mathrm{C}$ and $22^{\circ} \mathrm{C}$ at night. Thus, the mean relative humidity found in this study is well below the range recommended by the author. The same occurred with the values of temperature, taking into account that minimum temperatures occur at night and the maximum, during the day. Such weather conditions off the optimum range may have affected growth, flowering and fruiting of the plants, resulting in low productivity. The same situation was observed by SANTOS (2002), which reported reduced yields for an heirloom cucumber grown under protected environment, because climatic variables fell outside the ranges recommended in the literature. 
According to the yield results, it was found no significant interactions for treatments between the phenological stages, enabling separate analyses of the factors in each phase. Table 1 shows that the average yield of fruits and fruit weight per plant were significantly influenced by soil water potential, at $5 \%$ probability by the F-test, in both, vegetative and reproductive phases of culture.

TABLE 1. Summary of the analysis of variance for number of fruits per plant (NFP) and mass of fruits per plant (MFP), depending of soil water potentials during the vegetative and reproductive phases.

\begin{tabular}{lccccc}
\hline \multirow{2}{*}{ Source of Variation } & \multirow{2}{*}{\begin{tabular}{c} 
Degrees of \\
\cline { 3 - 5 }
\end{tabular}} & Freedom & \multicolumn{4}{c}{ Vegetative Phase } & \multicolumn{2}{c}{ Reproductive Phase } \\
\cline { 3 - 5 } & & Fruit & Weight & Fruit & Weight \\
\cline { 3 - 5 } Soil Water Potential & 3 & $110.4500 *$ & $1.4073 *$ & $89.7833 *$ & $1,2517 *$ \\
Residue & 16 & 32.5250 & 0.3717 & 18.2250 & 0.2591 \\
General Mean & & 18,2500 & 2.0086 & 16.4500 & 1.7705 \\
Coefficient of variance $(\%)$ & 31,25 & 30.35 & 25.95 & 28.75 \\
\hline
\end{tabular}

* Significant by the F-test at $5 \%$ of probability.

Overall, there were $21 ; 21 ; 19$ and 11 fruits per plant for the potentials of $15 ; 30 ; 60$ and $120 \mathrm{kPa}$ applied during the vegetative stage, and 20;18; 16 and 11 fruits per plant for the respective potentials applied during the reproductive phase. Regarding fruit weight, it was obtained values of $2.39,2.32,2.09$ and $1.24 \mathrm{~kg}$ per plant to water stress applied during the vegetative stage, and 2.27, $1.97,1.75$ and $1.09 \mathrm{~kg}$ per plant, during the reproductive phase, respectively.

Figure 1 shows a quadratic polynomial reduction $\left(\mathrm{R}^{2}=99.96 \%\right)$ in the number of fruits per plant (NFP) in the vegetative phase (VP), and a linear reduction $\left(\mathrm{R}^{2}=97.96 \%\right)$ in the reproductive phase (RP) due to increased water stress applied by the soil water potential. Similar trends of reduction can be observed in Figure 2 for mass of fruits per plant (MFP) in the vegetative phase (quadratic polynomial function, with $\mathrm{R}^{2}=99.99 \%$ ) and reproductive phase (linear, with $\mathrm{R}^{2}=$ $98.62 \%$ ) due to increases in soil water deficit.

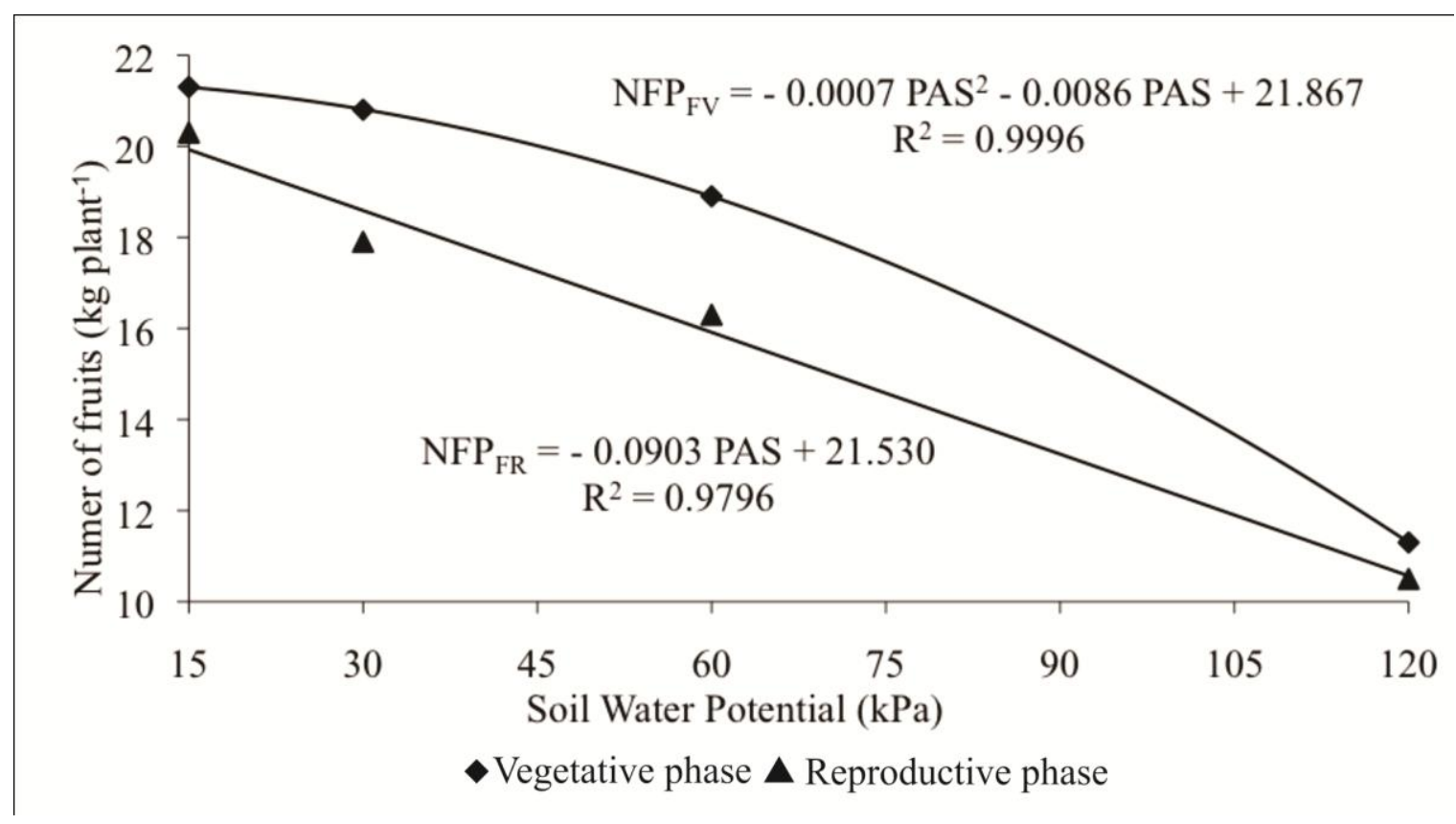

FIGURE 1. Number of fruits depending as a function of water soil potential applied to vegetative and reproductive phases of the Japanese cucumber culture. 


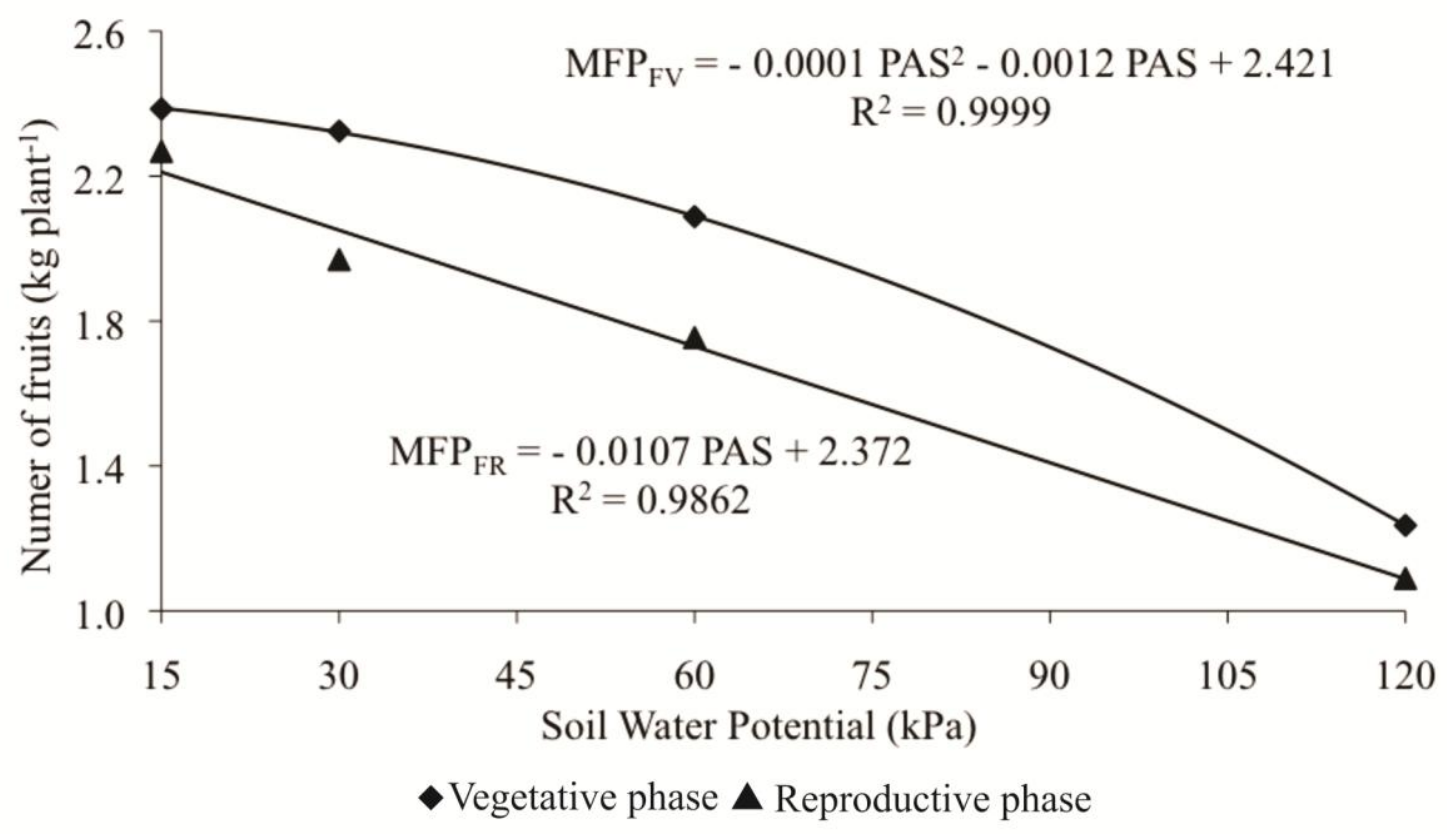

FIGURE 2. Fruit mass as a function of soil water potential applied to vegetative and reproductive phases of the Japanese cucumber culture.

The highest yields of this experiment, for both, number of fruits and for fruit mass, were obtained with irrigation on soil water potentials of 15 and $30 \mathrm{kPa}$ for the vegetative stage, and $15 \mathrm{kPa}$ for the reproductive stage. From this, it was considered the potential of $15 \mathrm{kPa}$ as a reference, i.e., the one that produced the greatest number of fruits and fruit weight per plant was set to express the percentage yield decrease of these two variables. Table 2 brings that the smallest percentage reduction of these variables was between the potentials 15 and $30 \mathrm{kPa}$ during the vegetative phase. However, this percentage was much more pronounced during the reproductive phase, as an indication that there is greater water requirement by the plants at this stage. Adding yet another focus of these results, it was recommend irrigation with potential values of $30 \mathrm{kPa}$ during the vegetative stage, and $15 \mathrm{kPa}$ during the reproductive phase, in order to save water and production costs.

TABLE 2. Percentage reduction in the number of fruits per plant (NFP) and mass of fruits per plant (MFP) for the vegetative (VS) and reproductive (RS) stages as a function of soil water potential.

\begin{tabular}{ccccc}
\hline \multirow{2}{*}{ Soil Water Potential (kPa) } & \multicolumn{4}{c}{ Relative Percentage Reduction } \\
\cline { 2 - 5 } & NFP - FV & MFP (kg) - FV & NFP - FR & MFP (kg) - FR \\
\hline 15 & 0.00 & 0.00 & 0.00 & 0.00 \\
30 & 2.35 & 2.58 & 11.82 & 13.16 \\
60 & 11.27 & 12.47 & 19.70 & 22.66 \\
120 & 46.95 & 48.19 & 48.28 & 51.96 \\
\hline
\end{tabular}

The results shown in Figures 1 and 2 and Table 2 denote the best yields for lower soil water potentials. This may be related to plant development, which, among other factors, is influenced by the addition of nutrients applied and made available to the plants through the presence of water in the soil due to the low potential applied. Another plausible explanation for these results is that the water shortage in the soil for high potentials may have enabled plant defense mechanisms, leading to stomatal closure and, consequently, decrease in plant turgidity. These findings reinforce the idea that water availability is essential for the yield of the Japanese cucumber, and that the crop responds positively to more frequent irrigation provided by the potentials of 15 and $30 \mathrm{kPa}$. 
These results are in agreement with SILVA \& MAROUELLI (1998), who declared that vegetables in general show better yield potential when subjected to the range of 10 to $40 \mathrm{kPa}$. Similar results were observed by BRAGA et al. (2006), who concluded that the optimum range of soil water potential to obtain higher melon yields in greenhouse varied between 30 and $40 \mathrm{kPa}$.

One may also note that the water deficit caused by increased potentials during the reproductive phase of the Japanese cucumber crop was more detrimental to plant yield. This decrease in yield during the reproductive stage of the culture can be explained by the occurrence of flower abortion and small fruits due to higher energy requirement to absorb the little water in soils with high potentials. Another possible explanation is that the Japanese cucumber fruit contains high water content in the pulp, resulting in commercial infeasibility of these fruits due to the damages caused by water deficit.

Similarly, SANTOS (2002) noted yield reduction in heirloom cucumber subjected to different soil water potentials during the vegetative season, despite not reporting a statistical effect. Furthermore, the author observed differences in yield when the treatments were applied during the reproductive phase of the culture, with negative linear correlations obtained according to potential increases.

Similarly to our results, MAROUELLI \& SILVA (2007) concluded that the fruiting stage of industry-processing tomato is the most sensitive to soil water deficiency. These authors observed higher yield with soil water potential of $35 \mathrm{kPa}$ applied during the vegetative stage, and $15 \mathrm{kPa}$ during the reproductive phase (or fruiting), and further noted that the yield decreased significantly with the increase in soil water potential from 5 to $120 \mathrm{kPa}$ during both phases of the culture. Still according to MAROUELLI \& SILVA (2006), the water potential that maximized processing tomato yield during the fruiting stage was $10 \mathrm{kPa}$.

WANG et al. (2007) found no significant differences for tomato yield under soil water potentials of $10 ; 20 ; 30 ; 40$ and $50 \mathrm{kPa}$. However, the authors recommended maintaining the soil water potential around $50 \mathrm{kPa}$ during the vegetative growth period and $20 \mathrm{kPa}$ during the fruiting phase to obtain higher yields.

Due to the limited reports related to different soil water potentials for cucurbits, and especially to the Japanese cucumber, it was compared the water stress applied in this work with other methodologies described in the literature, such as evapotranspiration and the use of evaporation tanks. From this, by comparing the decrease in yield of the Japanese cucumber obtained in this work to higher soil water deficiencies by SIMSEK et al. (2005), who evaluated how different limits of water stress affected cucumber yields based on crop evapotranspiration (ETc), found that the highest yield was obtained for the treatment of $100 \%$ of irrigation water replacement in relation to ETc. Additionally, the authors observed that the adjusted yield decreases linearly according to the treatments provided by water deficits of 50 and $75 \%$ of ETc.

In agreement with the related to water stress results obtained in this research, increased cucumber yield was observed by applying $100 \%$ of water replacement in a protected environment according to the "Class A" evaporation reported by AYAS \& DERMITAS (2009) and ERTEK et al. (2006), which also had yield decrease for lower replacement percentages of water in the soil.

Based on reduced tank evaporation, WANG et al. (2009) concluded that the treatments of 80 and $100 \%$ replacement of water in the soil showed no significant difference in the cucumber yield, implying that application of $80 \%$ of the evaporated water in the tank could save $14.3 \%$ water irrigation. This reinforces the idea that deficit irrigation can be viable environmentally and technoeconomically, depending on the culture, climate, region, and availability of irrigation water.

Table 3 shows fruit mass produced per hectare, the amount of water applied, and the water use efficiency (WUE) for soil water potentials according to the vegetative stage (VP) and reproductive (RP) of Japanese cucumber crop. 
TABLE 3. Mass of fruits, water applied and water use efficiency (WUE) in Japanese cucumber crop during the vegetative (VP) and reproductive (RP) phases.

\begin{tabular}{ccccccc}
\hline $\begin{array}{c}\text { Soil Water } \\
\text { Potential }(\mathrm{kPa})\end{array}$ & \multicolumn{2}{c}{$\begin{array}{c}\text { Fruit Weight } \\
\left(\mathrm{kg} \mathrm{ha}^{-1}\right)\end{array}$} & \multicolumn{2}{c}{$\begin{array}{c}\text { Water Consumption } \\
\left(\mathrm{m}^{3}\right)\end{array}$} & \multicolumn{2}{c}{$\begin{array}{c}\text { WUE } \\
\left(\mathrm{kg} \mathrm{m}^{-3} \mathrm{ha}^{-1}\right)\end{array}$} \\
\cline { 2 - 7 } & $\mathrm{VP}$ & $\mathrm{RP}$ & $\mathrm{VP}$ & $\mathrm{RP}$ & $\mathrm{VP}$ & $\mathrm{RP}$ \\
\hline 15 & 54,216 & 51,545 & $2,797.0$ & $2,796.0$ & 19.38 & 18.43 \\
30 & 52,818 & 44,761 & $2,743.7$ & $2,588.4$ & 19.25 & 17.29 \\
60 & 47,455 & 39,864 & $2,576.8$ & $1,982.5$ & 18.42 & 20.11 \\
120 & 28,091 & 24,761 & $2,048.6$ & $1,845.6$ & 13.71 & 13.42 \\
\hline
\end{tabular}

It can be seen from Table 3 that improved water use efficiencies (WUE) were obtained for treatments with irrigation potential of 15 and $30 \mathrm{kPa}$ during the vegetative stage, and with $60 \mathrm{kPa}$ during the reproductive phase. It is noteworthy that the worst WUE value was found for the treatment of $120 \mathrm{kPa}$ during both phases of the culture, with close values in both. From this, WUE decreased with an increase in soil water potential applied during the vegetative phase, and that during the reproductive phase, WUE was shown in an undefined manner.

WUE reflects the conversion rate of the fruit, i.e., the amount of fresh matter produced by each unit of water applied. Thus, the concept of WUE is relative, i.e., a greater efficiency does not correspond to increased yield. For greater efficiency found in this study, the estimated yield was $39,864 \mathrm{~kg} \mathrm{ha}^{-1}$ (for $60 \mathrm{kPa}$ during the reproductive phase).

In accordance with the results presented in this study, DERMITAS \& AYAS (2009) established that the cucumber plant showed higher WUE values for lower water stress rates applied by the "Class A" evaporation tank method. Conversely, WANG et al. (2007) noticed greater potential for higher WUE in soil water for tomato. The results corroborate with ZENG et al. (2009) report showing that major irrigation water deficiencies led to greater WUE, but to lower yields. In addition, MAROUELLI \& SILVA (2006) found that tomato WUE was not affected by irrigation regimes applied during the fruiting stage.

\section{CONCLUSIONS}

Crop yield showed a decreasing trend in relation to higher soil water potentials, with improved yield at potential values of 15 and $30 \mathrm{kPa}$ during the vegetative stage, and $15 \mathrm{kPa}$ during the reproductive stage for irrigation management.

To save water, irrigation is recommended with 30 and $15 \mathrm{kPa}$ potentials during the vegetative and reproductive phases, respectively.

The reproductive stage was more sensitive to water potential increases in the soil, with the occurrence of more dramatic yield reduction in relation to the vegetative stage.

The best water use efficiency was obtained for the potential of $60 \mathrm{kPa}$ applied during the reproductive phase, not reflecting higher yields of the crop, which was obtained with a potential of $15 \mathrm{kPa}$ applied during the vegetative phase.

\section{REFERENCES}

ALI, M.H.; HOQUE, M.R.; HASSAN, A.A.; KHAIR, A. Effects of deficit irrigation on yield, water productivity, and economic returns of wheat. Agricultural Water Management, Amsterdam, v.92, n.3, p.151-161, 2007.

AUJLA, M.S.; THIND, H.S.; BUTTAR, G.S. Fruit Yield and water use efficiency of eggplant (Solanum melongena L.) as influenced by different quantities of nitrogen and water applied through drip and furrow irrigation. Scientia Horticulturae, Amsterdam, v.112, n.2, p.142-148, 2007. 
ARAÚJO, W.F.; OLIVEIRA, G.A.; CARVALHO, F.K.; SILVA, W.M.; CRUZ, P.L.S.; MACIEL, F.C.S. Manejo da irrigação do meloeiro com base na evaporação do tanque classe A. Horticultura Brasileira, Brasília, v.28, n.4, p.495-499, 2010.

AYAS, S.; DEMIRTAS, C. Deficit irrigation effects on cucumber (Cucumis sativus L. Maraton) yield in unheated greenhouse condition. Journal of Food Agriculture \& Environment, Helsinki, v.7, n.3-4, p.645-649, 2009.

BERNARDO, S.; SOARES, A.A.; MANTOVANI, E.C. Manual de irrigação. 8.ed. Viçosa: UFV, 2006. $625 \mathrm{p}$.

BILIBIO, C.; CARVALHO, J.A.; MARTINS, M.A.; REZENDE, F.C.; FREITAS, E.A.; GOMES, L.A.A. Desenvolvimento vegetativo e produtivo da berinjela submetida a diferentes tensões de água no solo. Revista Brasileira de Engenharia Agrícola e Ambiental, Campina Grande, v.14, n.7, p.730735, 2010.

BRAGA, M.B.B.; DUENHAS, L.H.; SOUZA, C.M.P.; KLAR, A.E. Orientação geográfica de estufas de polietileno e potenciais de água no solo no cultivo do melão rendilhado híbrido 'nero'. Irriga, Botucatu, v.11, n.1, p.130-138, 2006.

CEASA-MG. CEASA MINAS CENTRAIS DE ABASTECIMENTO. Boletim diário de preços. Disponível em:

<http://minas.ceasa.mg.gov.br/detec/boletim/boletim_produto/boletim_produto.php>. Acesso em: 31 mar. 2009.

DANTAS, A.A.A.; CARVALHO, L.G.; FERREIRA, E. Classificação e tendência climática em Lavras, MG. Ciência e Agrotecnologia, Lavras, v.31, n.6, p.1862-1866, 2007.

DERMITAS, C.; AYAS, S. Deficit irrigation effects on pepper (Capsicum annuum L. Demre) yield in unheated greenhouse condition. Journal of Food, Agricultural and Environment, Helsinki, v.7, n.3-4, p.989-1003, 2009.

DOURADO NETO, D.; NIELSEN, D.R.; HOPANS, J.W.; PARLANGE, M.B. Programa SWRC: soil-water retention curve. Version 1.00. Piracicaba: ESALQ; Davis: University of Califórnia, 1995. Software.

ERTEK, A.; SENSOY, S.; GEDIK, I.; KUCUKYUMUK, C. Irrigation scheduling based on pan evaporation values for cucumber (Cucumis sativus L.) grown under field conditions. Agricultural Water Management, Amsterdam, v.81, n.1-2, p.159-172, 2006.

FERERES, E., SORIANO, A. Deficit irrigation for reducing agricultural water use. Journal of Experimental Botany, Oxford, v.58, n.2, p.147-159, 2007.

FERREIRA, D.F. SISVAR: um programa para análises e ensino de estatística. Revista Científica Symposium, Lavras, v.6, n.2, p.36-41, 2008.

FILGUEIRA, F.A.R. Novo manual de olericultura: agrotecnologia moderna na produção e comercialização de hortaliças. Viçosa: UFV, 2003. 402 p.

GENUCHTEN, M. T. Van. A closed-form equation for predicting the hydraulic conductivity of unsaturated soils. Soil Science Society American Journal, Madison, v.50, p.288-291, 1980.

GUANG-CHENG, S.; YU, Z.Z.; NA, L.; SHUANG-EN. Y.; XENG-GANG, X. Comparative effects of deficit irrigation (DI) and partial rootzone drying (PRD) on soil water distribution, water use, growth and yield in greenhouse grown hot pepper. Scientiae Horticulturae, Amsterdam, v. 119, p.11-16, 2008.

GOMES, L.A.A.; SILVA, E.C.; FAQUIN, V. Recomendações de adubação para cultivos em ambiente protegido. In: RIBEIRO, A.C.; GUIMARÃES, P.T.G.; ALVAREZ, V.H. (Ed.). Recomendações para o uso de corretivos e fertilizantes em Minas Gerais: $5^{\mathrm{a}}$ aproximação. Viçosa: UFV, 1999. p. 99-110. 
LALLA, J.G.; LAURA, V.A.; SEABRA JÚNIOR, S.; CARDOSO, A. I. I. Capacidade combinatória e heterose de linhagens de pepino do grupo japonês para caracteres de produção. Horticultura Brasileira, Campinas, v.28, n.3, p.337-343, 2010.

LOVELLI, S.; PERNIOLLA, M.; FERRARA, A.; TOMMASO, T. Di. Yield response factor to water (ky) and water use efficiency for Carthamus tinctorius L. and Solanum melongena L. Agricultural Water Management, Amsterdam, v.92, n.1-2, p.73-80, 2007.

MAGGI, M.F.; KLAR, A.E.; JADOSKI, C.J.; ANDRADE, A.R.S. Produção de variedades de alface sob diferentes potenciais de água no solo em ambiente protegido. Irriga, Botucatu, v.11, n.3, p.415-427, 2006.

MAROUELLI, W.A.; SILVA, W.L.C. Irrigação por gotejamento do tomateiro industrial durante o estádio de frutificação, na região de Cerrado. Horticultura Brasileira, Brasília, v.24, n.3, p.342-346, 2006.

MAROUELLI, W.A.; SILVA, W.L.C. Water tension thresholds for processing tomatoes under drip irrigation in Central Brazil. Irrigation Science, New York, v.25, n.4, p.411-418, 2007.

OLIVEIRA, F. de A. de; MEDEIROS, J.F. de.; LIMA, C.J.G.S. de.; DUTRA, I.; OLIVEIRA, M.K.T. de. Eficiência agronômica da fertirrigação nitrogenada e potássica na cultura do meloeiro nas condições do semi-árido nordestino. Caatinga, Mossoró, v.21, n.5, p.5-11, 2008.

PATANÈ, C.; COSENTINO, S.L. Effects of soil water deficit on yield and quality of processing tomato under a Mediterranean climate. Agricultural Water Management, Amsterdam, v.97, n.1, p.131-138, 2010.

POSSE, R.P.; BERNARDO, S.; SOUSA, E.F.; MESSIAS, G.P.; MONERAT, P.H.; GOTTARDO, R.D. Relação entre a produtividade do mamoeiro e o déficit hídrico (ky) na região Norte Fluminense. Revista Brasileira de Engenharia Agrícola e Ambiental, Campina Grande, v.13, n.2, p.158-164, 2009.

RODRIGUES, G.C.; PEREIRA, L.S. Assessing economic impacts of deficit irrigation as related to water productivity and water costs. Biosystems Engineering, London, v.103, n.4, p.536-551, 2009.

SANTOS, D.S. Efeitos da tensão de água no solo, na cultura do pepino (Cucumis sativus L.), utilizando sistema de irrigação automatizado. 2002. 60 f. Dissertação (Mestrado em Engenharia Agrícola) - Universidade Federal de Lavras, Lavras, 2002.

SEZEN, M.S.; YAZAR, A.; EKER, S. Effect of drip irrigation regimes on yield and quality of field grown bell pepper. Agricultural Water Management, Amsterdam, v.81, n.1-2, p, 115-131. 2006.

SGANZERLA, E. Nova agricultura: a fascinante arte de cultivar com os plásticos. 5. ed. Guaíba: Agropecuária, 1995. 342 p.

SILVA, W.L.C.; MAROUELLI, W. A. Manejo da irrigação em hortaliças no campo e em ambientes protegidos. In: FARIA, M.A.; SILVA, E.L.; VILELA, L.A.A.; SILVA, A.M. (Ed.). Manejo de irrigação. Poços de Caldas: UFLA/SBEA, 1998. p.311-348.

SIMSEK, M.; TONKAZ, T.; KACIRA, M.; COMLEKCIOGLU, N.; DOGAN, Z. The effects of different irrigation regimes on cucumber (Cucumis sativus L.) yield and yield characteristics under open field conditions. Agricultural Water Management, Amsterdam, v.73, n.3, p.173-191, 2005.

VILAS BOAS, R.C.; CARVALHO, J.A.; GOMES, L.A.A.; SOUSA, A.M.G.; RODRIGUES, R.C.; SOUZA, K.D. de. Avaliação técnica e econômica da produção de duas cultivares de alface tipo crespa em função de lâminas de irrigação. Ciência e Agrotecnologia, Lavras, v.32. n.2, p.525-531, 2008.

WANG, D.; KANG, Y.; WANA, S. Effect of soil matric potential on tomato yield and water use under drip irrigation condition. Agricultural Water Management, Amesterdam, v.87, n.2, p.180186, 2007. 
WANG, Z.; LIU, Z.; ZHANG, Z.; LIU, X. Subsurface drip irrigation scheduling for cucumber (Cucumis sativus L.) grown in solar greenhouse based on $20 \mathrm{~cm}$ standard pan evaporation in Northeast China. Scientia Horticulturae, v.123, n.1, p.51-57, 2009.

YUAN, B.-Z.; SUN, J.; KANG, W.; NISHIYAMA, S. Response of cucumber to drip irrigation water under a rainshelter. Agricultural Water Management, Amsterdam, v.81, n.1-2, p.145-158. 2006.

ZENG, C.-Z.; BIE, Z.-L.; YUAN, B.-Z. Determination of optimum irrigation water amount for drip-irrigated muskmelon (Cucumis melo L.) in plastic greenhouse. Agricultural Water Management, Amesterdam, v.96, n.4, p. 595-602, 2009. 